\title{
EXTRACTING THE CURVE-NUMBER MAP OF WATERSHEDS OF LIGHVAN CHAY IN GIS ENVIRONMENT
}

\author{
N. Taghavi \\ M.S in Civil Engineering-Water, Tabriz University, Faculty of Engineering
}

Published online: 15 February 2017

\begin{abstract}
One of the factors involved in the planning of water resources, is calculating the amount of runoff resulting from rainfall. Many of catchments in our country do not have hydrometric stations. Implementation water resource development projects, requires estimating these information.SCS method is one of the customary methods for solving this problem and as information required for this method, we can mention the runoff curve-number. This article has been performed about the Lighvan Chay catchment in East Azerbaijan and its purpose is the extraction of runoff curve number. To determine the curve-number, the land-use map and the soil map of the area have been prepared and then it is modulated in ArcGIS and the calculations have been performed. Using geographic information processing system, the weighted average value of the curve has been estimated under moisture condition and its amount is about 85.3 .According to that the highest level of catchment obtained about 86 . Comparing the results with curve numbers showed us that the obtained numbers are so close to each other and therefore the offered method is an easy and fast method for obtaining the curve number of catchments.
\end{abstract}

Key Terms: Raining, Runoff, GIS Methodology, SCS,curve number map, Lighvan Chay

\section{INTRODUCTION}

The Water is a vital component of the Earth, which is due to population growth and the resulting increase in the use of water resources, systematic water use planning seems necessary.

Author Correspondence, e-mail: author@gmail.com

doi: http://dx.doi.org/10.4314/jfas.v9i1s.709 
Runoff resulting from rainfall is one of the ways that can be effective on relieve water shortage. Therefore it is important to achieve a quantitative and qualitative level. There are several ways to calculate the level of runoff that we can mention on Heuristic method, Krieger method, Deacon Equation, Bush curve, Experimental Fuller Equation and cock method to estimate surface runoff. But at the catchments without hydrometric stations, we've got to use other methods. One of these methods which can be used in these conditions is called SCS which is offered by Soil Conservation Service of USA. In this method we used a parameter called $\mathrm{CN}$ which was related to number of curve. The number of curve was calculated from soil characteristics, vegetation covering, land-use and soil moisture conditions.

\section{Research Question}

1- The merit of using GIS in contrast to traditional method?

2- What accuracy does the determined runoff include by using the GIS tool the than the other methods?

\section{Research Hypotheses}

The hypotheses are as follow:

1- All plots of watershed were extracted in accurate way.

2- The resulted curve-number map shows the real potential of producing the area's runoff.

3- The area's average runoff to the other traditional methods includes the high accuracy.

\section{Literature}

Too many researchers have been done on the curve number methods, but Sherman was the first person who suggested the empirical relationship between rainfall and runoff in the form of unit hydrograph.

Insi Tekeli et al in 2006 determined the curve number for the area Gonesse India by using the data of RS. They used Landsat TM satellite maps for determining the land-useof area and then they used the NDVI index to determine the density of herbal cover. Rama Krishnan et al in 2009 used SCS-CN and GIS to identify areas of potential water in the catchment area of the river Kali fish place in India.

Sharma and Singh in 2012 determined the regions with the potential for runoff harvesting using GIS. In this research, they drew curve number and runoff potential map, using SCS method and with using ArcCN-Runoff tool and finaly with respect to the distance from the rural areas and farms, the water removal places were determined. 
Also in Iran several researches have been done in recent years. By using the techniques of remote sensing and GIS, Taheri and Landi (2006) prepared the catchment curve number of the Yellow River in Khuzestan with respect to runoff volume.

Akbarpour et al., in 2007 prepared the map of runoff Kame land use, which is located in the northern city of Torbat using two, and three-layer fuzzy method and Landsat ETM + satellite and then compared the results. They determined gradient map using a digital elevation model and capabilities of ERDAS and then determined the pastures status map using Tsld Cap Index andthen classified the pastures into three classes of average, poor and very poor. Finally, with the help of maps of soil, slope, geological formations and desert views, the map of Kame catchment runoff curve number was determined by hydrological soil group map prepared by SCS Software, using Arc View.

Barani et al. in 2012 prepared catchment curve number maps of Mansour Abad located in Birjand during 2002 until 2006 and the results showed that the amount of runoff curve number and the potential for increased during this period.

Ebrahimian et al in 1390 used NRCS-CN method with GIS for estimating the depth of runoff in mountain catchments in northern area in Mashhad. The results indicated the significant differences between the predicted runoff and observation data obtained from there.

\section{SCS method for calculating curve number}

Sherman(1949) was the first person who suggested the empirical relationship between rainfall and runoff in the form of unit hydrograph. Following these studies, Department "Soil Conservation Service" (1972), devised a method to calculate the losses of the shower (Chaw, 1988).

$\frac{\mathrm{F}_{\mathrm{a}}}{\mathrm{S}}=\frac{\mathrm{P}_{\mathrm{e}}}{\mathrm{P}-\mathrm{I}_{\mathrm{a}}}$

According to the principle of continuity:

$\mathrm{P}=\mathrm{P}_{\mathrm{e}}+\mathrm{I}_{\mathrm{a}}+\mathrm{F}_{a}$ 


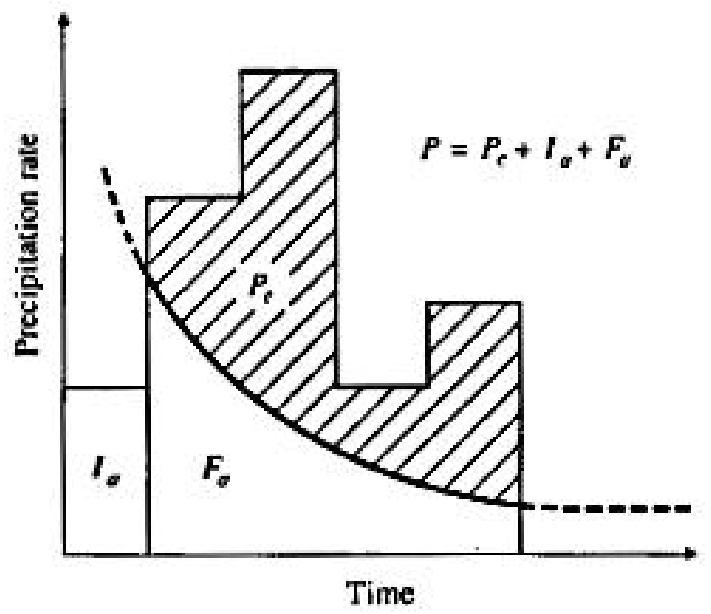

Fig1. Rainfall variables of SCS are determined from Combining Equations (1) and (2) $P_{e}$.

$$
P_{e}=\frac{\left(P-I_{a}\right)^{2}}{P-I_{a}+S}
$$

The basic equation to calculate the height of excess rainfall or direct runoff from a storm event is obtained by using the SCS methodology.

An empirical equation was obtained after checking the results obtained from several little experimental catchments.

$\mathrm{I}_{\mathrm{a}}=0.2 \mathrm{~S}$

According to this,

$\mathrm{P}_{\mathrm{e}}=\frac{(\mathrm{P}-0.2 \mathrm{~S})^{2}}{\mathrm{P}+0.8 \mathrm{~S}}$

when we draw a curve obtained from the data related to $\mathrm{P}$ and $\mathrm{P}_{\mathrm{e}}$ which are obtained from several catchments according to SCS method, there would be a curve which is shown at the bottom. 


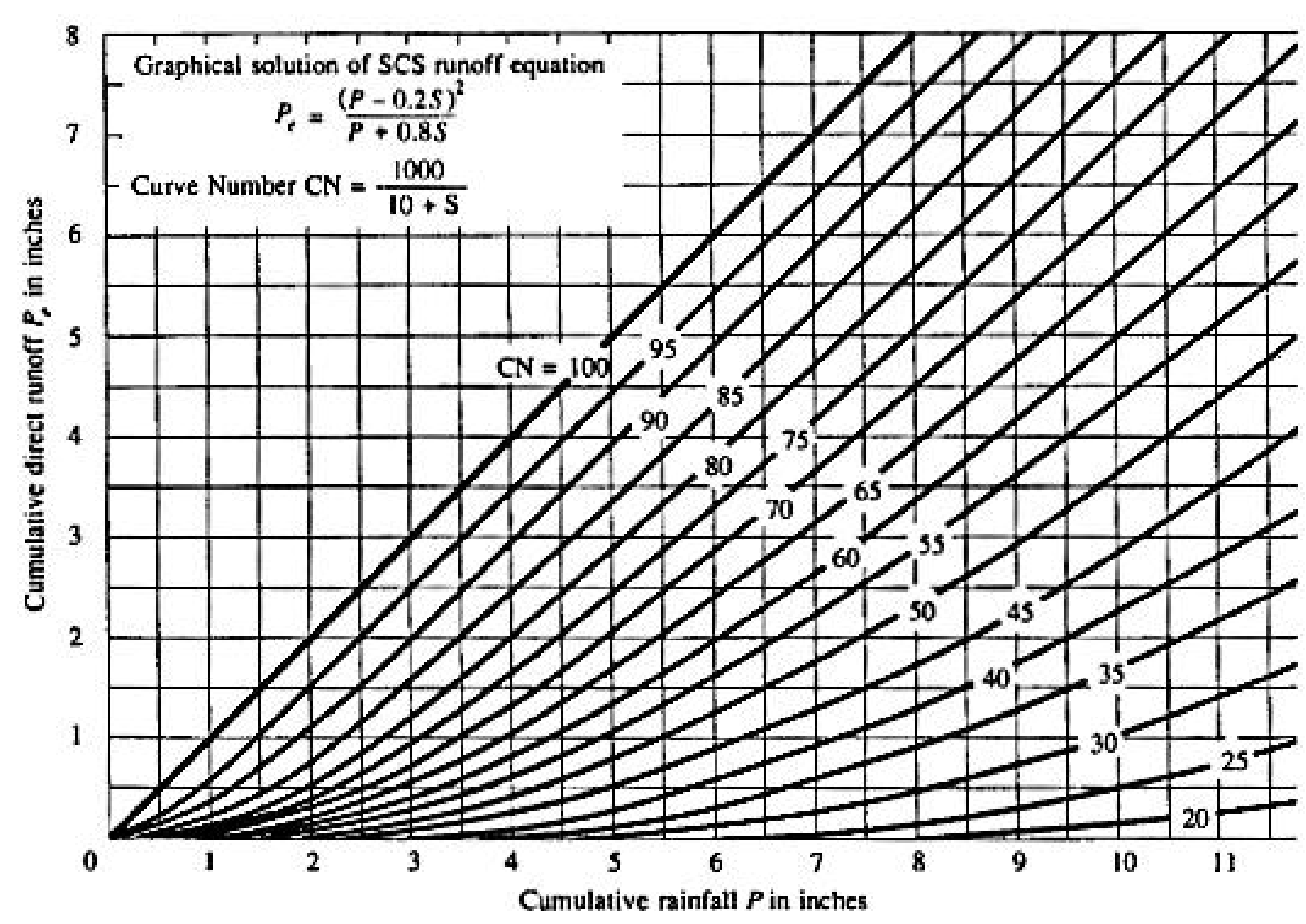

Fig.2. SCS runoff equation solution (Reference: Soil Preserving Service, 1972, Figure: 10-1)

To standardize the curves, the curve without dimension of $\mathrm{CN}$ number obtains in the range of $0 \unlhd \mathrm{CN} \unlhd 100$.

For Impermeable and juicy surfaces, $\mathrm{CN}=100$ and for natural surfaces includedCN $<100$.

There is an equation between $\mathrm{S}$ and curve number which $\mathrm{S}$ is calculated with inch.

$$
\mathrm{S}=\frac{1000}{\mathrm{CN}}-10
$$

(Chow, 1988)

\section{Calculating curve-number using observed data}

We can use 2 methods to calculate curve number using observed data, in first method, we interpolated the rainfall data and then the average height of the $\mathrm{CN}$ catchment area is calculated and then we obtain the value of $S$.

In second method using observed data about rainfall, the main function is being used which is provided by the soil protection organization.

$S=5 P+10 Q-5 Q \sqrt{\frac{5 P}{Q}}+4$ 
Assuming $\mathrm{I}_{\mathrm{a}}=0.2 \mathrm{~S}$ which

$\mathrm{P}=$ rainfall height $(\mathrm{mm})$

$\mathrm{Q}=$ runoff height $(\mathrm{mm})$

$\mathrm{S}=$ Maximum soil penetration $(\mathrm{mm})$

Then we estimated the curve number using below equation

$$
\mathrm{S}=25.4\left(\frac{1000}{\mathrm{CN}}-10\right)
$$

\section{Geographic Information System (GIS)}

Major challenges such as the increasing world population and their strategies, environmental pollution, destruction of forests, natural disasters (floods, earthquakes, etc.) have led human to think about establishing systems to provide easier and faster access to his location.

GIS or Geographic Information data system is a complex which consists data components, hardware, software, and expert users who are employed to collect, enter, storage, evaluate, marketing, management, analysis and display of spatial and descriptive data related to the work.

Data and spatial description in GIS is used in two ways of Descriptive and local. Descriptive information, show the nature and effects of the phenomenon and local data show the location where the phenomena are located in global systems.

\section{Location and geographical extent of the watersheds of Lighvan chay area}

Lighvan catchment is one of the AjiChay catchments and is located at northern slopes of Sahand, at the south of East Tabriz.

This catchment is located at $46^{\circ} 28^{\prime} 19^{\prime \prime}$ as geographical coordinates and $38^{\circ} 25^{\prime} 26^{\prime \prime}$ as latitude. It is about 75/81 kilometers square area. The highest point of catchment is 3596 meters height. The lowest point of catchment is 2140 meters height from the sea surface at the hydrometric station location. 


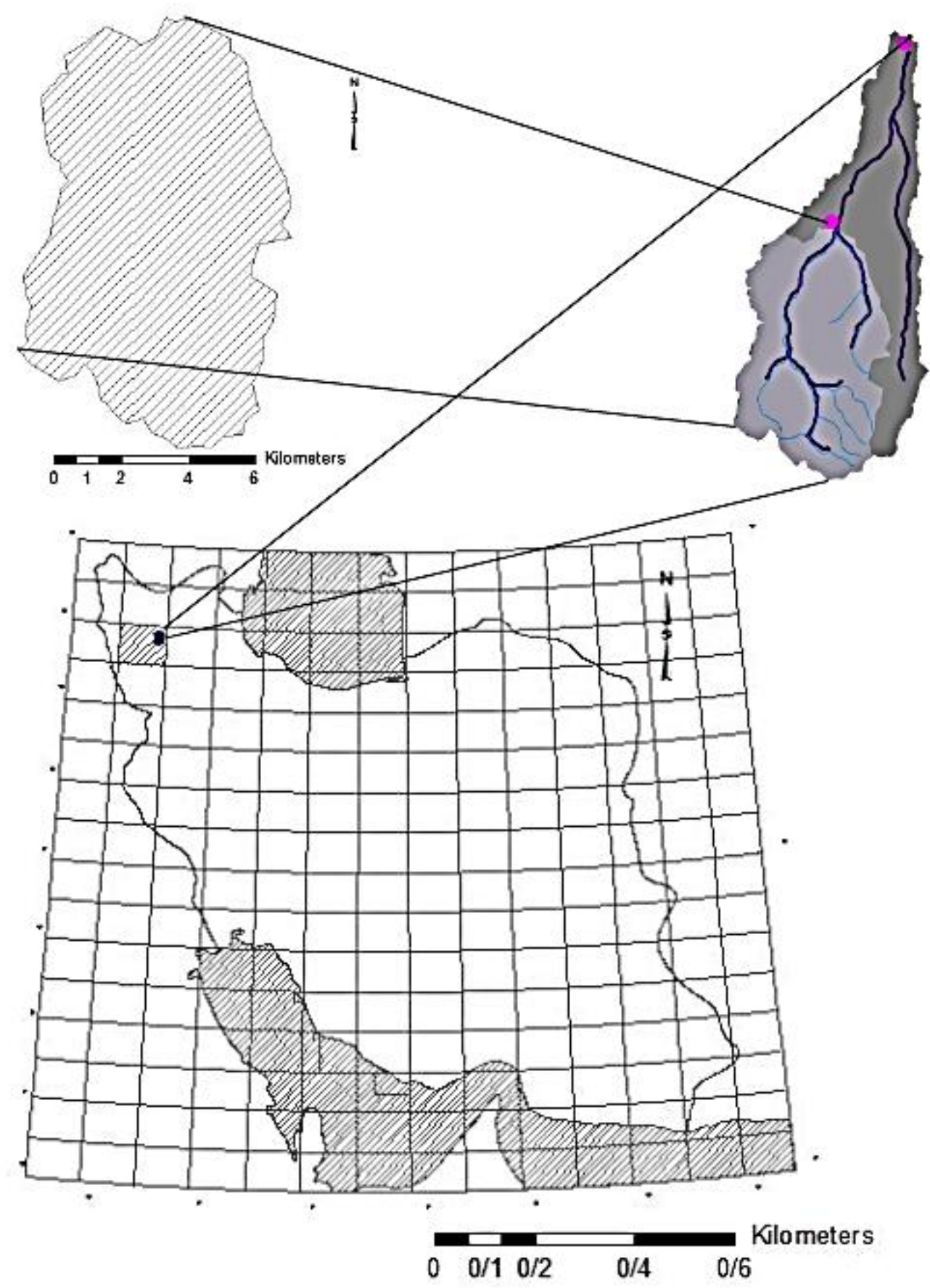

Fig.3. position of Lighvan Chay Area 
Table 1. Characteristics of the basin Lighvan Chay

\begin{tabular}{|c|c|c|c|c|c|c|}
\hline $\begin{array}{l}\text { Square } \\
(\mathrm{Km})\end{array}$ & $\begin{array}{c}\text { Environme } \\
\text { nt (Km) }\end{array}$ & $\begin{array}{l}\text { Distance to } \\
\text { the center of } \\
\text { the basin ( } \\
\mathrm{km} \text { ) }\end{array}$ & $\begin{array}{l}\text { Compressibil } \\
\text { ity } \\
\text { coefficient }\end{array}$ & $\begin{array}{l}\text { Coefficie } \\
\text { nt of form }\end{array}$ & $\begin{array}{r}\text { Coefficient } \\
\text { of thermal } \\
\text { spring }\end{array}$ & $\begin{array}{c}\text { Stretch } \\
\text { coefficie } \\
\text { nt }\end{array}$ \\
\hline 75.81 & 37.36 & 8.45 & 1.2 & 0.45 & 0.68 & 0.76 \\
\hline
\end{tabular}

\section{Curve Number Model}

Calculating catchment $\mathrm{CN}$, is based on physiographic characteristics, hydrologic soil groups, land-use, hydrological conditions and earlier soil moisture content of catchment.

Results from satellite images show that the Lighvan catchment has got three different types of sands including sandy loam soil, loam, and sandy clay loam.

Table 2 shows the area related to each type of sands.

Table 2. types of soils related to LighvanChay

\begin{tabular}{|c|c|c|}
\hline Square Percent & Square & Soil Type \\
\hline 1.905153824 & 1444260.18 & loam \\
\hline 13.18221824 & 9993184.092 & sandy loam \\
\hline 84.91262793 & 64370617.08 & sandy clay loam \\
\hline
\end{tabular}

Depending on the size and influence of soil, they divide into four hydrological groups. Depending on the type of soil available in Lighvan Chay, these hydrological groups have been classified in Table3.

Table 3. hydrological soil groups of LighvanChay catchment

\begin{tabular}{|c|c|c|}
\hline $\begin{array}{c}\text { Percent of } \\
\text { square }\end{array}$ & Area $\left(\mathrm{m}^{2}\right)$ & $\begin{array}{c}\text { hydrolic groups of } \\
\text { soil }\end{array}$ \\
\hline 86.81778176 & 65814877.26 & $\mathrm{C}$ \\
\hline 13.18221824 & 9993184.092 & $\mathrm{~B}$ \\
\hline
\end{tabular}


A 1/250000 map of Eastern Azerbaijan is used to prepare land use layer and after preparing needed file, the map enters in GIS software. Finally, the modified map includes three types of uses. Table 4 shows the area of different uses related to Lighvan catchment.

Table 4. Land use of Lighvan catchment

\begin{tabular}{|c|c|}
\hline Land applications & Area $\left(\mathrm{m}^{2}\right)$ \\
\hline $\begin{array}{c}\text { Without water land } \\
\text { applications }\end{array}$ & 10509518.84 \\
\hline Rangeland or pasture & 64508395.07 \\
\hline Residential area & 790147.4456 \\
\hline
\end{tabular}

\section{Calculating lighvan catchment NC using SCS method}

During modulating hydrological soil groups and land use in ArcGIS software, the area of each land with special property is calculated which are shown in table 5.

Table 5. Hydrologic soil groups according to the type of land use

\begin{tabular}{|c|c|c|}
\hline Land applications & Area (m2) & Soil type \\
\hline $\begin{array}{c}\text { Without water land } \\
\text { applications }\end{array}$ & 10509518.84 & $\mathrm{C}$ \\
\hline Rangeland or pasture & 10031136.21 & $\mathrm{~B}$ \\
\hline Residential area & 627291.1121 & $\mathrm{C}$ \\
\hline Residential area & 162856.3336 & $\mathrm{C}$ \\
\hline Rangeland or pasture & 54477258.85 & $\mathrm{C}$ \\
\hline
\end{tabular}


Table 6. Runoff curve numbers for selected agricultural, suburban, and urban land uses (antecedent moisture condition,$I_{a}=0.2 \mathrm{~S}$

Land Use Description

Hydrologic Soil Group

\begin{tabular}{|c|c|c|c|c|}
\hline & & & & \\
\hline & $\mathbf{A}$ & B & $\mathrm{C}$ & $\mathbf{D}$ \\
\hline \multirow{2}{*}{$\begin{array}{l}\text { Cultivated land 1: without conservation treatment } \\
\text { with conservation treatment }\end{array}$} & 72 & 81 & 88 & 91 \\
\hline & 62 & 71 & 78 & 81 \\
\hline Pisture or range land: poor condition & 68 & 79 & 86 & 89 \\
\hline good condition & 39 & 61 & 74 & 80 \\
\hline Mcadow: good condition & 30 & 58 & 71 & 78 \\
\hline \multirow{2}{*}{$\begin{array}{l}\text { Wood or forest land: thin stand, poor cover, no mulch } \\
\qquad \text { good cover } 2\end{array}$} & 45 & 66 & 77 & 83 \\
\hline & 25 & 55 & 70 & 77 \\
\hline \multirow{2}{*}{$\begin{array}{l}\text { Open Spaces, lawns, parks, golf courses, cemeteries, etc. } \\
\text { good condition: grass cover on } 75 \% \text { or mote of the area } \\
\text { fair condition: grass cover on } 50 \% \text { to } 75 \% \text { of the area }\end{array}$} & 39 & 61 & 74 & 80 \\
\hline & 49 & 69 & 79 & 84 \\
\hline Commercial and business areas ( $85 \%$ impervious) & 89 & 92 & 94 & 95 \\
\hline Industrial districts ( $72 \%$ impervious) & 81 & 88 & 91 & 93 \\
\hline \multicolumn{5}{|l|}{ Residential3: } \\
\hline Average $\%$ impervious 4 & & & & \\
\hline $1 / 8$ acre or less & 77 & 85 & 90 & 92 \\
\hline $1 / 4$ acre & 61 & 75 & 83 & 87 \\
\hline $1 / 3$ acre & 57 & 72 & 81 & 86 \\
\hline $1 / 2$ acre & 54 & 70 & 80 & 85 \\
\hline 1 acre & 51 & 68 & 79 & 84 \\
\hline Paved parking lots, roofs, driveways, etc. 5 & 98 & 98 & 98 & 98 \\
\hline \multicolumn{5}{|l|}{ Streets and roads: } \\
\hline paved with curbs and storm sewers 5 & 98 & 98 & 98 & 98 \\
\hline gravel & 76 & 85 & 89 & 91 \\
\hline dirt & 72 & 82 & 87 & 89 \\
\hline
\end{tabular}

1 For a more detailed description of agricultural land use curve numbets, refer to Soil Conservation Service, 1972. Chap, 9

2 Good cover is protected from erazine and littet and brush cover soil.

3 Curve numbers are computed assuming the runoff from the house and driveway is directed towands the stree with a minimum of roof water directed to lawns where additional infiltration could occur.

4 The remaining pervious areas (lawn) are considered to be in good pasture condition for these curve numbers Sin some warmer climates of the country a curve number of 95 may be used. 
Table 7. Calculating Curve-Number of Lighvn chay watershed

\begin{tabular}{|c|c|c|c|c|}
\hline $\begin{array}{c}\text { Land } \\
\text { applications }\end{array}$ & Area $\left(\mathrm{m}^{2}\right)$ & $\begin{array}{c}\text { Percent of } \\
\text { Area }\end{array}$ & $\mathrm{CN}$ & CN*Area \\
\hline $\begin{array}{c}\text { Without } \\
\text { appler land }\end{array}$ & 10509518.84 & 13.86332622 & 88 & 924837658.3 \\
\hline $\begin{array}{c}\text { Rangeland or } \\
\text { pasture }\end{array}$ & 10031136.21 & 13.23228168 & 79 & 611899308.9 \\
\hline $\begin{array}{c}\text { Residential } \\
\text { area }\end{array}$ & 627291.1121 & 0.827472832 & 81 & 50810580.08 \\
\hline $\begin{array}{c}\text { Residential } \\
\text { area }\end{array}$ & 162856.3336 & 0.214827197 & 81 & 13191363.02 \\
\hline $\begin{array}{l}\text { Rangeland or } \\
\text { pasture }\end{array}$ & 54477258.85 & 71.86209208 & 86 & 4031317155 \\
\hline
\end{tabular}

$\bar{V}: \bar{v}=\frac{\sum_{i=1}^{n} A_{i}(C N)_{i}}{\sum_{i=1}^{n} A_{i}}=85$

\section{Determining curve number according to Observational data}

Hytographs of rainfalls are received from East Azarbaijan Regional Water Authority as scanned files and then the level of hourly rainfall estimates. After extraction, levels of Floodwater transport to excel files, and then some good results of rainfall are chosen to calculate Precipitation surplus.

\section{CONCLUSION AND DISCUSSION}

The overall objective of this study, is systematically assess and quantitatively predict the runoff resulting from rainfall and estimate the factors of LighvanChay catchment.

For this reason we first calculate the number of curve and then we estimate the level of runoff. Another objective of this study was to evaluate the efficiency and accuracy of this method, in the areas without hydrometric stations. 
In this research, for estimating curve number of Lighvan catchment, first the data is been collected and then enters into GIS software. Then the data processes and $\mathrm{CN}$ number estimates for each cell. Finally curve number gets compared using observed data, which these results are as following results:

1. Hydrological soil groups which are very important for calculating curve number, extract from (soil type) map in ARCGIS 10.2. According to the results, usual types of soils in points are $\mathrm{C}$ type.

2. A 1/250000 map of Eastern Azerbaijan is used to prepare land use layer and after preparing needed file, the map enters in GIS software. According to results, $1.04 \%$ of area is used as Residential area, $13.86 \%$ is used as Dry-land farming area and $85.1 \%$ is used as Pastures.

3. For calculating curve number of catchment, first hydrological soil groups and land use areas combine in ArcGIS and then curve number calculates using SCS standard table. The weight average of catchment is 85.3.

The amount of curve number calculates according to rainfall data and level of runoff in different years and the results have been compared throw computer software. This compare shows that the results don't have significant difference.

\section{REFERENCES}

[1] Safavi, H. (1968). Hydrology og engineering, Arkan Danesh Pub.

[2]Sedghi, H. (1975). Hydrometeorology(studying the effective factors on rivers' discharge). Agricultural collage, Tabriz University.

[3] Afshr, A. (1999). Hydrology engineering, Power Ministry Pub.

[4] Simafar, Sh, Hydrology Engineering, Sahand Industrial University.

[5] Mahdavi, M. (2003). Hydrology Application, Tehran University Pub. $2^{\text {nd }}$ version

[6] Ghodrati, M. (2013). Training the application of ARCGIS in Water Engineering, Simay-e Danesh Pub.

[7] Mohammadi, H. and Panahi, N. (2007). Estimating the valume of runoff by using the SCS and GIS methods in Ghale Chay area, Geography (Scentific-Research journal of Iran Geography), No. 10 and 11.

[8] Barani, G., Yaghubzade, M. and Akbarpour, A. (2012). Using the land set satellites' images (ETM+) and IRS in supplying the curve number plots of Mansourabad Birjand catchment runoff area, Iran Water Sources' researches, No. 4, 106-109.

[9] Javadi, M.R., Mirdar Heijarani, F. and Chatr Simab, Z. (2012). Estimating the runoff's height by using the curve number in software environment ArcGIS by ArcCN-Runoff (case 
study: Azardrood Cachment Area), testing application journal and geographical information system in planning, No. 3, 55-62.

[10] Motiei, H. (2005). Application of GIS in Hydrology, Tehran, the giant barriers' committee.

[11] Motiei, H. (2006). Familiarity with ArcView and side software, Tehran, Water and Electricity industry Pub.

[12] Rasooli, A.A. (2005). Analyzing the Geographical Information System Technology. Tabriz University Pub.

[13] Panahi, N. (2006). Estimating the runoff by using the Curve Number by using the Geographical Information System, M.S. thesis, Geography Collage, Tehran University. [14] Akhundi, A. (2002). Studying the Curve Number Model in Estimating the Torrent by using the Geographical Information Systems, M.S. Thesis, Basic Sciences and Natural Sources Collage, Tarbiat Modarres University.

[15] Golami Somea et al., (2012). Extracting the Unite Hydrograph of Geomorphologic in base of Waterfall-Line- Sources, Agriculture Collage, Tabriz University.

[16] Hajizade Baroogh, M. (2011). Presenting the raining Model- Geomorphological Runoff in base of Non-Linear Waterfall Sources Concepts, M.S. Thesis, Civil Collage, Tabriz University.

[17] Banihashem, S.M. (2005). Hydrological Modeling of Catchment Area by Using the Satellite Data. M.S. Thesis, Humanistic and Social Collages, Tabriz University.

[18] Water Emgineering Standard, (1989). The Physiography Order in Watershed Areas, Budget and Planning Organization's Technical Criteria Studying Office, Power Ministry. [19]"Applied Hydrology.1988Ven.Te Chow.

[20] National Engineering Handbook Hydrology. United States Department of Agriculture 1997.

[21]Show,E .Hydrology ,Dover inc, New York.1970

[22] J. P. Patil, A. Sarangi , O. P. Singh ,A. K. Singh,T. Ahmad. "Development of a GIS Interface for Estimation of Runoff." Water Resour Manage 22 (2008): 1221-1239.

[23] X. Zhan, M.L. Huang. "ArcCN-Runoff: an ArcGIS tool for generating curve number and runoff maps." (Environmental Modeling \& Software) 2004.

[24] Inci Tekeli. Y. Akguül. S. Dengiz. O. Aküzüm. T. Estimation of flood discharge for small watershed using SCS curve number and geographic information system. 2006, River Basin Flood Management Journal, pp: 527-538. 
[25] M. Ebrahimian, A. Ainuddin Nuruddin, M.A.B. Mohd Soon, A.M. Sood. "Application of NRCS-curve number method for runoff estimation in a mountainous watershed." CJES 2011, pp:103-114

[26] Terjam Nayak, Verma M.K, Hema Bindu.S "SCS curve number method in Narmada Basin."Intrnational journal of Geomatics and Geoscinces, Volume 3, No 1, 2012, pp: 219-228

\section{How to cite this article:}

Taghavi N. Extracting the curve-number map of watersheds of lighvan chay in gis environment. J. Fundam. Appl. Sci., 2017, 9(1S), 511-524. 